\title{
UJI SITOTOKSISITAS DAN ANTIPROLIFERATIF FRAKSI ETIL ASETAT EKSTRAK ETANOL BIJI JINTEN HITAM (Nigella sativa, Lour) TERHADAP SEL MIELOMA
}

\section{THE CYTOTOXICITY AND ANTIPROLIFERATIF TEST ETHYL ACETATE FRACTION OF ETHANOLIC EXTRACT OF BLACK SEED (Nigella sativa, Lour) OF MYELOMA CELL}

\author{
Laela Hayu Nurani \\ Universitas Ahmad Dahlan Yogyakarta \\ Jl. Prof. Dr. Supomo, Yogyakarta, Telp (0274) 379418
}

\begin{abstract}
Abstrak
Kanker merupakan penyakit karena sel yang berproliferasi secara pesat dan terus-menerus (proliferasi). Jinten hitam (Nigella sativa, L.) merupakan salah satu tanaman yang berkhasiat sebagai antikanker. Penelitian ini bertujuan untuk mengetahui aktivitas sitotoksisitas dan antiproliferasi ekstrak etanol dari biji jinten hitam (Nigella sativa, L.) terhadap sel Mieloma. Ekstrak etanol diperoleh dari serbuk biji jinten hitam dengan metode penyarian maserasi yang selanjutnya dilakukan fraksinasi dengan etil asetat. Uji sitotoksisitas dilakukan dengan menginkubasi sel Mieloma dengan perlakuan ekstrak etanol biji jinten hitam (Nigella Sativa, L.) dengan beberapa seri kadar yaitu 2000; 1000; 500; 250 dan 62,5 $\mathrm{gg} / \mathrm{ml}$. Pengujian dilakukan dengan metode MTT kemudian dihitung persen kematiannya. Nilai $L C_{50}$ dihitung dengan menggunakan analisis probit. Penelitian dilanjutkan dengan uji antiproliferasi dengan menentukan doubling time pada perlakuan sampel kadar $125 \mu \mathrm{g} / \mathrm{ml}$ dan 62,5 $\mu \mathrm{g} / \mathrm{ml}$ dengan kontrol sel pada jam ke-24, 48, dan 72. Hasil penelitian menunjukkan bahwa ekstrak etanol biji jinten hitam bersifat sitotoksik terhadap sel Mieloma dengan harga $L_{50}$ sebesar 177,01 $\mathrm{\mu g} / \mathrm{ml}$. Hasil uji antiproliferasi menunjukkan adanya penghambatan pertumbuhan. Nilai doubling time sebesar 253 jam pada kadar 62,5 $\mu \mathrm{g} / \mathrm{ml}, 298,4 \mathrm{jam}$ pada kadar $125 \mu \mathrm{g} / \mathrm{ml}$ sedangkan pada kontrol sel adalah 54,52 jam,
\end{abstract}

Kata kunci : Kanker, biji Jinten Hitam (Nigella sativa L.), sitotoksik 


\begin{abstract}
Cancer is the formation of new tissue which is abnormal and malignant. A group of cells suddenly become disorganized and reduplicate themselves rigorously (hyperproliferation). Nigella sativa L. is one of the herbs which have an anticancer effect. This research aims to assess the cytotoxic and antiproliferative effect of Nigella sativa L. ethanol extract of Myeloma cells. Ethanolic extract was produced from Nigella sativa L. powder with maseration method. The cytotoxicity test was done by incubating Myeloma cells with the treatment concentration group of N. sativa L. ethyl acetic fraction of ethanolic extract 2000; 1000; 500; 250; and 62,5 $\mu \mathrm{g} / \mathrm{ml}$, respectively. The test was done with an MTT method and then with a calculation of its death percentage. The $L_{50}$ is calculated using a probit analysis method. The test was then continued with the antiproliferative test to assess the doubling time at treatment concentration 125; 62,5 $\mathrm{\mu g} / \mathrm{ml}$ and cellular control at hours 24, 48, and 72. The results showed that Nigella sativa L. ethanolic extract had cytotoxic activity towards the Mieloma cells with an $L C_{50}$ value $177,01 \mu \mathrm{g} / \mathrm{ml}$. The antiproliferative test showed that there was a growth inhibition, even cell death at the extract treatments. The doubling time was 253 hours at 62,5 $\mathrm{gg} / \mathrm{ml}$ concentration, 298,4 hours at $125 \mathrm{ug} / \mathrm{ml}$, while the cell control had 54,52 hours.
\end{abstract}

Key word : Cancer, Nigella sativa L, cytotoxic 


\section{PENDAHULUAN}

Mieloma disebut juga multiple myeloma, adalah kanker sumsum tulang yang mempengaruhai produksi sel darah merah, sel darah putih, dan sel stem. Myeloma merupakan kanker darah terbesar kedua. Di negara maju kanker ini berkembang pesat dan semakin banyak menyerang orang yang berusia lebih muda (Durie, 2001).

Usaha penyembuhan kanker yang sangat sulit mendorong ditemukannya senyawa kemopreventif yaitu senyawa yang dapat digunakan untuk menghambat, menunda atau membalikkan proses terjadinya kanker (Surh, 2003). Senyawa kemopreventif dibagi menjadi 2 kategori yaitu blocking agent dan suppressing agent. Beberapa senyawa kemopreventif memiliki mekanisme aksi keduanya, blocking dan suppressing (Surh, 2002; Surh, 1999). Sayur dan buah-buahan merupakan sumber terbaik bahan pencegah kanker (Jones, 2000). Strategi penemuan antikanker meliputi sintesis organik murni, studi metabolisme spesifik sel kanker, serta eksplorasi senyawa alam (Gibbs, 2000).

Nigella sativa, L (dikenal dengan nama jinten hitam) dengan kandungan kimia asam linoleat (Rouhou, et al., 2007), minyak lemak esensial (Burits and Bucar, 2000), nigellone (Dakhakhny et al., 2002), terpenoid (sikloart-23metil-7,20,22-triena-3b,30-diol), dan sukrosa (Mehta et al., 2008). Nigella sativa dilaporkan mempunyai efek antioksidan (Burits and Bucar, 2000), penghambatan lipooksigenase (Dakhakhny et al., 2002), antiinflamasi, antikanker (Tariq, 2008), analgesik (Randhawa, 2008), sitotoksik terhadap hepatoma HepG2 cell line (Thabrew et al., 2005), hepatocelluler carcinoma cells (Hassan et al., 2008)

Berdasarkan data-data yang tersedia tersebut, maka dapat dikatakan bahwa tanaman Nigella Sativa, Lour memiliki potensial untuk dikembangkan sebagai agen antikanker. Penelitian ini bertujuan untuk meneliti efek sitotoksik dan antiproliferatif ekstrak etanol biji jinten hitam terhadap sel mieloma.

\section{METODE PENELITIAN}

\section{Bahan}

Sel mieloma diperoleh dari koleksi Laboratorium Penelitian dan Pengujian Terpadu Universitas Gadjah Mada (UGM). Bahan tanaman berupa biji jinten hitam yang diperoleh dari tanaman yang tumbuh di Kulon Progo Yogyakarta. Bahan uji sitotoksik dan antiproliferatif: (3-(4,5 dimetiltiazol -2-il)- 2,5 difenil tetrazolium bromida) (Zigma), PBS (Phosphate Buffer Saline) (Merck), Biru tripan (Gibco), Tripsin EDTA $0.25 \%$ (Gibco), Media RPMI (Rosewell Park Memorian Institute) 1640, Fetal Bovine Serum (FBS) 10\% $(\mathrm{v} / \mathrm{v})$ (Gibco), Penisilin -streptomisin $1 \%(\mathrm{v} / \mathrm{v})(\mathrm{Gibco})$, Fungison 0,5\% (v/v) (Gibco), PBS (Phospate Buffer Saline), Trypsin-EDTA $\quad 0.25 \%$, Dymethyl sulfoxide (DMSO), Sodium Dodecyl Sulphate (SDS) $10 \%$ dalam asam klorida $0,1 \mathrm{~N}$ (Merck).
Alat
Alat yang digunakan dalam penelitian ini adalah maserator, LAF, mikropipet, hemositometer, flask, plate, conical, sentrifus, dan inkubator $\mathrm{CO}_{2}$. 


\section{Jalannya Penelitian}

\section{a. Pembuatan Ekstrak}

Biji tanaman Nigella sativa, L. yang telah kering, dibersihkan dengan cara dicuci dengan air mengalir beberapa kali sampai semua kotoran yang melekat hilang. Biji kering kemudian diserbuk menggunakan blender dan diayak. Serbuk diekstraksi dengan pelarut etanol $70 \%$. Filtrat kemudian dikumpulkan kemudian diuapkan menggunakan vaccum rota evaporator. Ekstrak yang diperoleh dipindahkan ke dalam cawan kemudian diuapkan kembali diatas penangas air dan diangin-anginkan sampai diperoleh ekstrak yang kental. Selanjutnya dilakukan fraksinasi dengan etil asetat, fraksi yang larut etil asetat dipekatkan dan digunakan untuk sampel uji.

\section{b. Uji Sitotoksisitas dengan metode MTT}

Seratus $\mu 1$ suspensi sel Mieloma dengan kepadatan $3 \times 10^{4}$, didistribusikan ke dalam sumuran-sumuran pada 96-well plate bersama ekstrak uji pada berbagai kadar masing-masing $2000 ; 1000 ; 500$; 250; dan $125 \mu \mathrm{g} / \mathrm{ml}$ dari stok $16.10^{3}$ dan diinkubasikan selama 24 jam. Untuk kontrol digunakan $100 \mu \mathrm{l}$ suspensi sel ditambah ke dalam sumuran yang berisi $100 \mu 1$ medium RPMI 1640, dan untuk blanko digunakan $100 \mu \mathrm{l}$ suspensi sel ditambahkan ke dalam sumuran yang berisi DMSO dan media. Selanjutnya sel diinkubasi dalam inkubator dengan aliran $5,0 \% \mathrm{CO}_{2}$ pada suhu $37^{\circ} \mathrm{C}$. Pada akhir inkubasi pada masing-masing sumuran ditambah $10 \mu 1$ MTT sebesar 5 $\mathrm{mg} / \mathrm{ml}$ dalam FBS steril, kemudian plate diinkubasi lagi selama 4 jam pada suhu $37{ }^{\circ} \mathrm{C}$ dengan aliran $\mathrm{CO}_{2} 5,0 \%$. Sel yang hidup akan bereaksi dengan MTT membentuk warna ungu. Reaksi dihentikan dengan reagen stoper SDS, diinkubasi semalam pada suhu kamar. Serapan dibaca dengan ELISA reader pada panjang gelombang $550 \mathrm{~nm}$.

Persentase kematian dihitung dengan cara jumlah sel hidup kontrol dikurangi jumlah sel hidup perlakuan dibagi jumlah sel hidup kontrol dikalikan $100 \%$. Harga $L C_{50}$ dihitung dengan analisis Probit.

\section{c. Uji Antiproliferasi}

Sel distarvasi (dipuasakan) terlebih dahulu selama 24 jam dengan media kultur yang mengandung 0,5\% FBS (Fetal Bovine Serum). Selanjutnya sel ditumbuhkan di dalam plate dengan medium yang ditambahkan kontrol dan larutan uji dengan seri kadar yang tidak mematikan (di bawah $\mathrm{LC}_{50}$ ). Sampling dilakukan pada jam ke 24, 48 dan 72 . Data yang diperoleh berupa absorbansi sel hidup yang diperoleh dari hasil pengukuran dengan ELISA reader dengan panjang gelombang $550 \mathrm{~nm}$. Data jumlah sel yang hidup pada jam ke- $0,24,48$ dan 72 dibuat grafik antara jumlah sel yang hidup dan lama waktu inkubasi (jam), kemudian ditentukan perbedaan waktu untuk mencapai jumlah dua kali sel awal (mengetahui doubling time), caranya buat persamaan regresi linear antara log jumlah sel hidup dan waktu tiap perlakuan, kemudian dari persamaan dimasukkan nilai log jumlah dua kali sel awal sebagai nilai y maka akan diperoleh nilai x sebagai doubling time nya. Doubling time merupakan parameter antiproliferatif suatu bahan uji, jika doubling time nya lebih panjang dari kontrol negatif, maka dikatakan 
bahan uji mempunyai daya antiproliferatif.

\section{HASIL DAN PEMBAHASAN}

a. Uji Sitotoksisitas Fraksi Etil Asetat Ekstrak Etanol Biji Jinten Hitam terhadap sel Mieloma
Intensitas warna ungu ini mempunyai korelasi langsung dengan jumlah sel yang hidup (Mosman, 1993). Kristal formazan dapat dilihat pada Gambar 1.

Hasil perhitungan persentase kematian sel dapat dilihat pada Tabel I.

Tabel I. Hasil uji sitotoksisitas fraksi etil asetat ekstrak etanol biji jinten hitam terhadap sel Mieloma

\begin{tabular}{|cccc|}
\hline $\begin{array}{c}\text { Kadar } \\
(\boldsymbol{\mu g} / \mathbf{m l})\end{array}$ & Log kadar & $\begin{array}{c}\text { Persentase } \\
\text { kematian sel }(\%)\end{array}$ & Probit \\
\hline 2000 & 3,301 & 97,41 & 6,949 \\
1000 & 3,000 & 93,23 & 6,496 \\
500 & 2,698 & 81,85 & 5,914 \\
250 & 2.397 & 58,40 & 5,188 \\
125 & 2,096 & 39,57 & 4,737 \\
\hline
\end{tabular}

Prinsip dasar uji sitotoksisitas adalah kerja enzim mitokondria pada sel aktif yang memetabolisme garam tetrazolium, sehingga terjadi pemutusan cincin tetrazolium oleh enzim dehidrogenase yang menyebabkan tetrazolium berubah menjadi formazan yang tidak larut dan berwarna ungu.

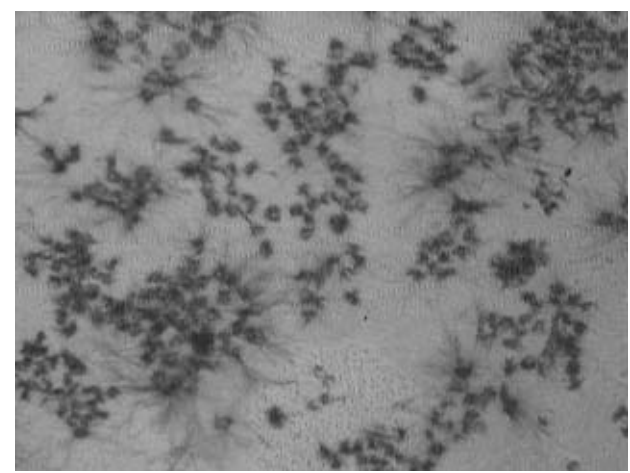

Gambar 1. Kristal formazan
Dari hasil yang tertera pada Tabel I terlihat bahwa semakin besar kadar senyawa uji yang diberikan pada suspensi sel, semakin besar pula persentase kematian sel yang dihasilkan. Hal ini menunjukkan bahwa potensi ketoksikan ekstrak etanol biji jinten hitam adalah tergantung pada kadar.

Dari data uji sitotoksisitas dapat dihitung kadar yang menyebabkan kematian $50 \%$ sel yang diuji $\left(\mathrm{LC}_{50}\right)$ dengan metode analisis probit. Data persentase kematian sel karena pengaruh perlakuan (sampel) dikonversikan dalam nilai probit, kemudian dibuat persamaan regresi linear antara log kadar dengan probit. Persamaan regresi yang diperoleh yaitu $y=1,9025 x+0,7232$ dengan harga $r=0,997$. Hal ini dapat dilihat pada Gambar 2. 


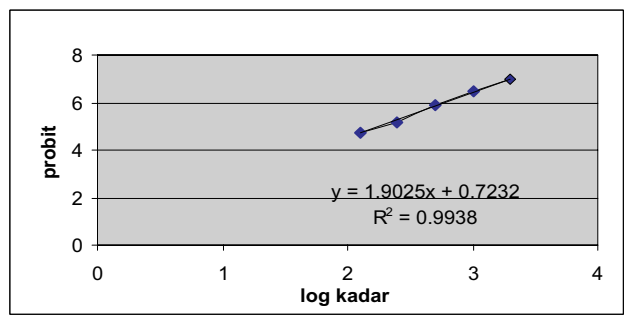

Gambar 2. Hubungan antara Log kadar fraksi larut etil asetat ekstrak etanol biji jinten hitam dengan Probit.

Harga $\mathrm{LC}_{50}$ diperoleh dengan memasukkan probit 5 ke dalam persamaan garis lurus tersebut, kemudian diperoleh harga $x$. Antilog dari harga $x$ merupakan $\mathrm{LC}_{50}$. Hasil perhitungan $\mathrm{LC}_{50}$ diperoleh $177,01 \mu \mathrm{g} / \mathrm{ml}$. Ini berarti pada kadar tersebut senyawa uji dapat menyebabkan kematian sebesar $50 \%$ dari jumlah sel yang dicoba. Semakin kecil konsentrasi yang dibutuhkan untuk mematikan $50 \%$ jumlah sel berarti senyawa tersebut semakin toksik. Hasil uji sitotoksisitas digunakan untuk menentukan konsentrasi yang akan digunakan untuk uji antiproliferatif. Dipilih dua dosis di bawah $\mathrm{LC}_{50}$ yaitu 125 dan $62,5 \mathrm{ìg} / \mathrm{mL}$. Selanjutnya dilakukan uji antiproliferatif untuk melihat pengaruh fraksi etil asetat ekstrak etanol jinten hitam terhadap kinetika proliferasi sel.

Besarnya hubungan antara log kadar sampel dengan probit yang dihitung dengan koefisien korelasi adalah 0,997 . Hal ini menunjukkan adanya hubungan yang linear antara log kadar dengan probit karena $\mathrm{r}$ hitung $>\mathrm{r}$ tabel $(\mathrm{r}$ tabel $=0,8783$ ). Hasil dari uji regresi linear menunjukkan adanya perbedaan yang bermakna dari masing- masing konsentrasi terhadap persen kematian.

\section{a. Uji Antiproliferatif}

Pada uji antiproliferatif digunakan dua seri kadar yaitu 125 dan $62,5 \mu \mathrm{g} / \mathrm{ml}$ yang ditentukan dari harga $\mathrm{LC}_{50}$ pada uji sitotoksisitas, kadar-kadar tersebut memiliki persentase kematian dibawah $\operatorname{LC}_{50}(177,01 \mu \mathrm{g} / \mathrm{ml})$. Pemilihan kadar dari larutan uji yang digunakan adalah dibawah $\mathrm{LC}_{50}$ agar sel dapat diamati pertumbuhannya serta morfologinya karena sel tidak banyak yang mati. Apabila digunakan kadar diatas $\mathrm{LC}_{50}$ dikhawatirkan sel banyak yang mati sebelum 72 jam inkubasi sehingga pengamatan kinetika proliferasi tidak dapat dilakukan dan profil pertumbuhannya tidak terlihat.

Pada pengamatan morfologi antara sel mieloma yang mengalami perlakuan ekstrak etanol biji jinten dibandingkan sel mieloma kontrol akan memperlihatkan perubahan morfologi yang berbeda. Sel yang hidup dari kontrol akan terlihat bergerombol dan menempel didasar sumuran, bentuknya bulat cemerlang sedangkan pada perlakuan terlihat adanya sel yang mati. Hal ini dapat dilihat dari bentuknya sudah berubah yaitu sudah tidak bulat lagi dan tampak gelap. Hasil pengamatan morfologi sel mieloma dapat dilihat pada Gambar 3. 


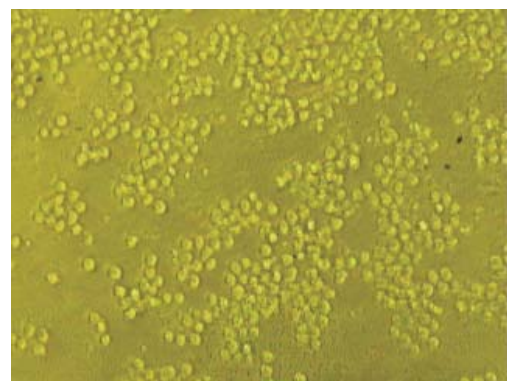

(A)

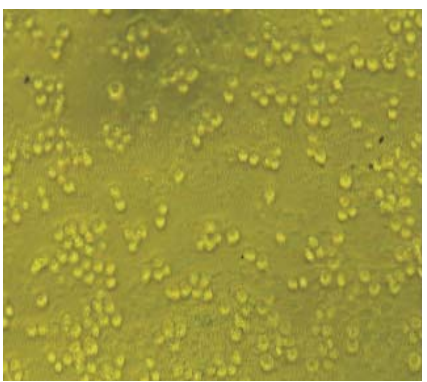

(B)

Gambar 3. Morfologi sel mieloma dalam sumuran setelah diinkubasi 24 jam (A) kontrol sel (B) perlakuan kadar $125 \mu \mathrm{g} / \mathrm{ml}$.

Uji antiproliferatif ini dilakukan dengan metode MTT. Data yang diperoleh berupa absorbansi sel hidup. Sampel yang berwarna dapat memberikan absorbansi sehingga absorbansi yang terbaca tidak hanya warna ungu yang sebanding dengan jumlah sel yang hidup tapi juga warna dari sampel, sehingga diperlukan adanya kontrol sampel diperlukan untuk mengeliminasi pengaruh absorbansi dari sampel yang berwarna. Hasil absorbansi perlakuan dikurangi absorbansi dari kontrol sampel, kemudian dikonversikan ke dalam jumlah sel hidup. Data jumlah sel hidup dan absorbansinya dapat dilihat pada Tabel II.

Tabel II. Variasi jumlah sel dan absorbansi yang ditetapkan dengan metode MTT pada panjang gelombang $550 \mathrm{~nm}$

\begin{tabular}{|c|c|}
\hline Jumlah sel hidup & Absorbansi \\
\hline 5000 & 1,050 \\
\hline 10000 & 1,123 \\
\hline 15000 & 1,196 \\
\hline 20000 & 1,200 \\
\hline 25000 & 1,247 \\
\hline
\end{tabular}

\begin{tabular}{|l|l|}
\hline 30000 & 1,278 \\
\hline 35000 & 1,273 \\
\hline 40000 & 1,331 \\
\hline 45000 & 1,337 \\
\hline 50000 & 1,344 \\
\hline
\end{tabular}

Dari kurva baku pada Tabel II tersebut kemudian dibuat persamaan regresi linear antara jumlah sel hidup dan absorbansi yang digunakan untuk mengkonversikan absorbansi sel hidup dari setiap perlakuan persatuan waktu. Dari persamaan regresi linear tersebut diperoleh persamaan kurva baku $y=$ $6,13 \cdot 10^{-6} x+1,069$ dengan harga $\mathrm{r}=$ 0,961. Grafik kurva baku dapat dilihat pada Gambar 4.

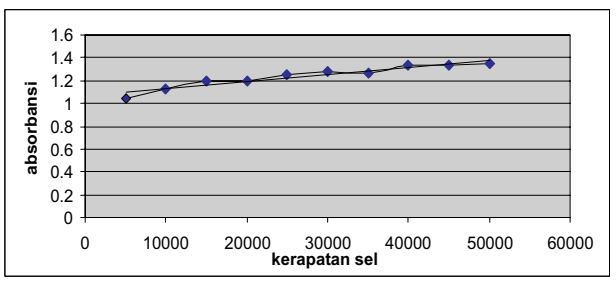

Gambar 4. Grafik hubungan jumlah sel hidup dengan absorbansinya 
Hasil absorbansi sel hidup pada masing-masing perlakuan persatuan waktu, yaitu pada kontrol sel, sampel kadar 125 dan $62,5 \mu \mathrm{g} / \mathrm{ml}$ dimasukkan pada persamaan kurva baku di atas sehingga diperoleh data jumlah sel. Hasil uji antiproliferatif dapat dilihat pada Tabel III.
Dari harga doubling time tersebut dapat diketahui penghambatan ekstrak etanol biji $N$. Sativa, Lour. terhadap kecepatan sel untuk berproliferasi dengan membandingkan harga doubling time kontrol dengan harga doubling time sampel.

Harga doubling time diperoleh

Tabel III. Hasil pengamatan uji antiproliferatif fraksi etil asetat ekstrak etanol biji jinten hitam terhadap sel Mieloma

\begin{tabular}{|lcccc|}
\hline \multirow{2}{*}{ Perlakuan } & \multicolumn{4}{c|}{ Log jumlah sel hidup jam ke- } \\
\cline { 2 - 5 } & $\mathbf{0}$ & $\mathbf{2 4}$ & $\mathbf{4 8}$ & $\mathbf{7 2}$ \\
\hline kadar $125 \mu \mathrm{g} / \mathrm{ml}$ & 4,301 & 3,643 & 4,564 & 4,129 \\
kadar $62,5 \mu \mathrm{g} / \mathrm{ml}$ & 4,301 & 3,862 & 4,598 & 4,190 \\
Kontrol sel & 4,301 & 4,666 & 4,665 & 4.548 \\
\hline
\end{tabular}

Dari Tabel III dapat diketahui jumlah sel hidup pada jam ke-0, 24, 48, dan 72 , selanjutnya dibuat persamaan regresi linear antara log jumlah sel hidup dengan waktu inkubasi. Hasil regresi tersebut digunakan untuk menghitung harga doubling time. dari nilai log dua kali jumlah sel awal sebagai Y dikurangi harga intersep dari persamaan regresi linear waktu inkubasi versus log jumlah sel hidup, kemudian dibagi dengan slopenya. Hasil regresi linear dan harga doubling time sel mieloma pada berbagai perlakuan dan kontrol sel ditampilkan pada Tabel IV.

Tabel IV. Hasil pengamatan regresi linear dan harga doubling time sel Mieloma pada berbagai perlakuan kadar fraksi etil asetat ekstrak etanol biji jinten hitam

\begin{tabular}{|c|l|c|c|c|c|}
\hline $\begin{array}{c}\text { Kadar } \\
(\boldsymbol{\mu g} / \mathbf{m l})\end{array}$ & \multicolumn{1}{|c|}{ Persamaan } & slope & $\mathbf{Y}$ & $\begin{array}{c}\text { Doubling } \\
\text { Time } \\
(\mathbf{j a m})\end{array}$ & $\mathbf{R}$ \\
\hline 125 & $\mathrm{y}=1,688.10^{-3} \mathrm{x}+4,089$ & $1,688.10^{-3}$ & 4,602 & 298,4 & 0,135 \\
\hline 62,5 & $\mathrm{y}=1,679.10^{-3} \mathrm{x}+4,177$ & $1,679.10^{-3}$ & 4,602 & 253 & 0,171 \\
\hline Kontrol sel & $\mathrm{y}=3,083 \cdot 10^{-3} \mathrm{x}+4,434$ & $3,083.10^{-3}$ & 4,602 & 54,53 & 0,555 \\
\hline
\end{tabular}

Doubling time merupakan waktu yang diperlukan oleh sel untuk menggandakan dirinya menjadi dua kali lipat.
Berdasarkan dari Tabel IV terlihat perlakuan kontrol sel memiliki harga doubling time terkecil. Hal ini me- 
nunjukkan bahwa kecepatan proliferasi sel dapat diperlambat dengan memberikan ekstrak etanol biji N. Sativa, Lour. Terlihat juga bahwa harga doubling time perlakuan sampel kadar $125 \mu \mathrm{g} / \mathrm{ml}$ lebih besar daripada sampel kadar 62,25 $\mu \mathrm{g} / \mathrm{ml}$. Semakin tinggi konsentrasi fraksi etil asetat ekstrak etanol biji jinten hitam maka penghambatan proliferasinya pada sel mieloma semakin besar pula.

Kemampuan fraksi etil asetat ekstrak etanol biji N. Sativa, Lour. dalam menghambat proliferasi sel juga dapat dilihat dari harga slope. Harga slope yang semakin besar membuktikan bahwa semakin banyak jumlah sel yang hidup. Pada kontrol sel harga slope lebih besar daripada harga slope sampel. Hal tersebut dapat dilihat pada grafik waktu inkubasi versus log jumlah sel hidup pada berbagai perlakuan dan kontrol

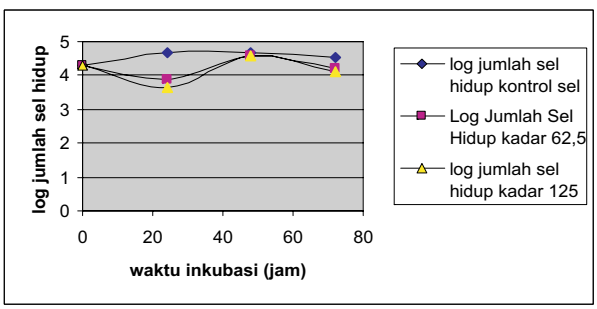

Gambar 5. Grafik log jumlah sel Mieloma yang hidup sebagai fungsi waktu pada berbagai perlakuan kadar dan kontro

Pada grafik (Gambar 5) terlihat bahwa slope sampel berada di bawah slope kontrol. Hal ini menunjukkan adanya penghambatan perkembangan sel setelah pemberian fraksi etil asetat ekstrak etanol biji jinten hitam $(N$. Sativa, Lour.). Dari data slope hasil uji antiproliferasi dapat diketahui bahwa dengan pemberian fraksi etil asetat ekstrak etanol biji jinten hitam $(N$. Sativa, L.) terhadap sel mieloma baik pada kadar $125 \mu \mathrm{g} / \mathrm{ml}$ maupun pada kadar $62,5 \mu \mathrm{g} / \mathrm{ml}$ mampu menghambat perkembangan sel lebih lambat dari kontrol. Hal tersebut ditunjukkan dari harga slope. Semakin besar harga slope maka semakin singkat doubling timenya. Harga doubling time pada kontrol sel lebih kecil daripada sampel yang artinya bahwa dengan tidak adanya pemberian senyawa uji, sel mampu berproliferasi dalam waktu yang lebih singkat. Hal ini menunjukkan bahwa ekstrak etanol biji jinten hitam mampu memacu cell cycle arrest.

Kandungan zat aktif dalam fraksi etil asetat ekstrak etanol biji jinten hitam yang diduga bersifat sitotoksik dan antiproliferatif adalah minyak lemak esensial (Mbarek et al., 2007), saponin (terpenoid dan steroid) (Boskabady et al., 2000), tymol (Hajar, 2008). Kemungkinan titik tangkap senyawa alam seperti terpenoid berdasarkan mekanismenya sebagai antikanker antara lain menekan pertumbuhan sel CAV-1 dan menginduksi apoptosis sel kanker (Palozza et al, 2008). Saponin bekerja sebagai antikanker dengan menginduksi cell cycle arrest dan apoptosis sel (Bachran et al., 2008).

\section{KESIMPULAN}

Fraksi etil asetat ekstrak etanol biji jinten hitam (Nigella sativa, L.) mempunyai aktivitas sitotoksik secara in vitro terhadap sel Mieloma, dengan $\mathrm{LC}_{50}$ $177,01 \mu \mathrm{g} / \mathrm{ml}$. Ekstrak ini juga mempunyai efek antiproliferatif terhadap sel Mieloma dengan kemungkinan mekanisme memacu cell cycle arrest. 


\section{UCAPAN TERIMAKASIH}

Ucapan terimakasih kami tujukan kepada Kementerian Riset dan Teknologi yang telah mendanai penelitian ini melalui dana RISTEK INSENTIF DASAR Tahun 2009-2010.

\section{DAFTAR PUSTAKA}

Bachran, C., Bachran, S., Sutherland, M., Bachran, D., Fuchs, H., 2008, Saponins in tumor therapy, Mini Rev Med Chem, 8, 575-84.

Boskabady MH, Shiravi N, 2000, Inhibitory effect of Nigella sativa on histamine (H1) receptors of isolated guinea pig tracheal chains. Eur Respir J;16:461s

Burits M, Bucar F, 2000, Antioxidant activity of Nigella sativa essential oil, Phytother Res, 14(5):323-8

Dakhakhny, M.E., Madi, N.J., Lembert, N., and Ammon, H.P.T., 2002, Nigella sativa oil, nigellone and derived thymoquinone inhibit synthesis of 5-lipoxygenase products in polymorphonuclear leukocytes from rats. $J$. Ethnopharmacol, 81(2)161-164

Durie B.G.M., 2001, Multiple Myeloma: What's New, CA Cancer J Clin 51;271-272

Gibbs, J.B., 2000, Anticancer drug targets: growth factors and growth factor signalling, J. Clin Invest, 105, 109-111

Hassan, M.I., Mabrouk, G.M., Shenata, H.H., 2008, Antineoplastic Effects of Bee Honey and Nigella sativa on Hepatocellular
Carcinoma Cells, Integr Cancer Ther, 9(4)

Hajar, U., 2008, Fakta Tibun Nabawi : Habbatus Sauda, Madu, dan Minyak Zaitun, http://www. muslimah.or.id, diakses pada tanggal 24 Juni 2011.

Jones, CLA.,2000. Herbal Aids For Cancer. Nutrition Science News dalam Chiro.org. www. Chiro.org.

Mbarek, L.A., Mouse, H.A., Elabbadi, N., Bensalah M., Gamouh A., Aboufatima R., Benharref A., ChaitA., Kamal, M, Dalal, A and. Zyad, A., 2007, Anti-tumor properties of blackseed (Nigella sativa L.) extracts, Braz J Med Biol Res 40(6) 2007

Mehta B.K., Sharma, U., Agrawal, W., Pandit, V., Nidhi J., and Gupta, M., 2008, Isolation and characterization of new compounds from seeds of Nigella sativa, Medicinal Chemistry Research, 17(2)462-473

Mosman, T., 1993, Journal of Immunological Method, hal. 55-63, 65.

Randhawa, M.A., 2008, Black seed, Nigella sativa, Deserves more attention, $J$ Ayub Med Coll Abbottabad, 20(2) 1-2

Rouhou, S.C., Besbes, S., Hentati, B., Blecker, C., Deroanne, C., and Attia, H., 2007, Nigella sativa L.: Chemical composition and physicochemical characteristics of lipid fraction, Food Chemistry, 101(2), 673-681 
Surh, Y., 2003. Cancer Chemoprevention With Dietary Phytochemicals, Nature Revs.3.:768-80

Surh, Y., 2002, Anti-tumor promoting potential of selected of spice ingredients with antioxidative and anti-inflammatory activities: a short review, Food and Chem Tox, 40, 1091-1097

Surh, Y., 1999, Molecular Mechanism of Chemopreventive Effect of Selected Dietary and Medicinal Phenolic Substances, Mut Res, 428, 305-327

Tariq, M., 2008, Nigella sativa Seeds: Folklore Treatment in Modern Day Medicine, Saudi J Gastroenterol, 14(3): 105-106
Thabrew, M.I., Mitry, R.R., Morsy, M.A., and Hughes, R.D., 2005, Cytotoxic effects of a decoction of Nigella sativa, Hemidesmus indicus and Smilax glabra on human hepatoma HepG2 cells, Life Sciences, 77(12):1319-1330

Palozza, P., Sestito, R., Picci., N., Lanza, P., Monego, G., Ranelletti, FO., 2008, The sensitivity to \{beta\}Carotene Growth-Inhibitory and Pro-apoptotic Effects is Regulated by Caveolin-1 Expression in Human Colon and Prostate Cancer Cells, Carcinogenesis, Catholic University School of Medicine. 